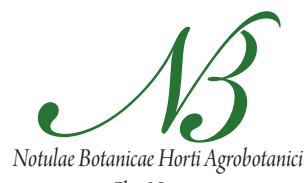

Clij-Napoca

\title{
Study of Cytostatic and Cytotoxic Activity of Several Polyphenolic Extracts Obtained from Vitis vinifera
}

\author{
Ancuța NECHITA ${ }^{1}$, Valeriu V. COTEA ${ }^{1}$, Constantin-Bogdan NECHITA ${ }^{1 *}$ \\ Rotinberg R. PINCU², Cosmin-Teodor MIHAI', Cintia Lucia COLIBABA' \\ ${ }^{1}$ University of Agricultural Sciences and Veterinary Medicine, Faculty of Horticulture, 3 Aleea Mihail \\ Sadoveanu, 700490 Iaşi, Romania; bnechita@gmail.com ( ${ }^{*}$ corresponding author) \\ ${ }^{2}$ The Institute of Biological Researches, 47 Lascăr Catargiu Street, 700107 Iaşi, Romania \\ ${ }^{3}$,Al.I.Cuza" University of Iaşi, Faculty of Biology, 22 A Blv. Carol I, 700505 Iaşi, Romania
}

\begin{abstract}
The study of polyphenolic extracts from skins, seeds, grape pomace and lees is justified by the huge amount of information from specialized literature, drawing attention to the many pharmacological effects of these biomolecules. The concentrated vegetal extracts obtained from seeds, skins, grape pomace and lees (yeast deposit after fermentation) were characterized according to their content of total polyphenols, anthocyanins, dry matter, ash and $\mathrm{pH}$. The biological material used in the in vitro testing experiments in order to study cytostatic and cytotoxic effects were stabilized cultures of HeLa cancer cells, uncontaminated with mycoplasma and derived from a human uterine cervix carcinoma. Another action of the cytostatic substances could be exerted upon the cell proliferation process. The cell division process of the HeLa cell cultures treated with seeds by-product showed remarkable quantitative changes. The study has also evidenced a great number of dead cells in the composition of the treated HeLa cell cultures, their existence pointing out that the bioactive agent induced a major decrease of the cells viability. The obtained results in the context of the complex evaluation of the in vitro antitumoral property of the extracts, obtained from seeds, skins, grape pomace and wine lees from the 'Arcaş' grape variety, on HeLa cells cultures, have demonstrated the significant cytostatic and cytotoxic potential of the seeds polyphenolic biopreparate. The results obtained show that polyphenolic extracts from Vitis vinifera seeds act as cytostatic and cytotoxic agents.
\end{abstract}

Keywords: apoptosis, by-products of wine making, protein synthesis, tumor cells

\section{Introduction}

In Romania, as well as in other grapevine growing countries, grapes are used mostly for wine production. Grapes contain complexes of polyphenolic compounds, of which only one third is found in must (T,ârdea et al., 2010), whereas the rest is easily accessible and relatively easy to extract from skins, seed and pulp. Therefore, it was decided that a systematic study is necessary in order to characterize their properties.

The capacity of red grapevine varieties to accumulate different classes of polyphenols, which used to be a rather narrow segment of research, is now becoming a wider and wider field of interest. The study of polyphenolic extracts from skins, seeds, grape pomace and lees is justified by the huge amount of information from specialized literature, drawing attention to the many pharmacological effects of these biomolecules. From these polyphenolic products, bactericide (Baydar et al., 2004), anti-anemic and antiinflamatory (Joi et al., 2010; Youdim et al., 2002), antioxidant (Katalinic et al., 2009) cardio-vascular (Cheng et al., 2007) and even oncolitic (Kaur et al., 2006; Paun Roman et al., 2008) effects are reported. Their compre- hensive influence at the level of the animal or human organism is part of complex interactions between phenolic bio-molecules and cellular, sub-cellular and molecular structures (membranes, organelles, enzymes, metabolites, nucleic acids etc.) that create possibilities of intervention as non-enzymatic protectors, as acceptors and donors of electrons, as metabolic and membranotrophic modulators (Hosu et al., 2011).

The main aim of this study is to identify new anti-tumor preparations made from plant material high in polyphenols and based on a preliminary in vitro screening on neoplasic cells cultures.

\section{Material and methods}

In the in vitro screening test cycle four alcoholic extracts were used from skins, seeds, grape pomace and lees from the 'Arcaş' grape variety. The extraction was done in a Soxhlet apparatus with an extraction ratio of 1:10 (g plant material $/ \mathrm{mL}$ alcohol). The four alcoholic extracts were concentrated in a rotary evaporator at a temperature of $30^{\circ} \mathrm{C}$, from $200 \mathrm{~mL}$ to $20 \mathrm{~mL}$. 
Total polyphenols were determined spectrophotometrically according to Folin-Ciocâlteu (Singleton et al., 1999); anthocyanin compounds according to Ribereau Gayon-Sonestreet (Ribereau-Gayon, 1965) and dry matter gravimetrically. The reference substance was gallic acid.

The biological material used in the in vitro testing experiments in order to study cytostatic and cytotoxic effects were stabilized cultures of HeLa cancer cells, uncontaminated with mycoplasma and derived from a human uterine cervix carcinoma. Growth was maintained in DMEM medium (Dulbeco's Modified Essential Medium, Biochrom AG, Germany) supplemented with $10 \%$ fetal serum (Sigma, Germany), $100 \mu \mathrm{g} / \mathrm{mL}$ streptomycin (Biochrom AG, Germany), $100 \mathrm{IU} / \mathrm{mL}$ penicillin (Biochrom AG, Germany) and $50 \mu \mathrm{g} / \mathrm{mL}$ amphotericin B (Biochrom AG, Germany), at a density of $5 \times 10^{5}$ cells, in a humidified $5 \% \mathrm{CO}_{2}$ atmosphere at $37^{\circ} \mathrm{C}$ (Doyle et al., 1998; Leiter et al., 1965).

When the cells confluenced and reached the monolayer stage of culture, they were detached by means of $0.25 \%$ trypsin $+0.02 \%$ EDTA (ethylenediaminetetraacetic acid, Biochrom AG, Germany), re-suspended in normal medium in order to obtain the necessary cellular mass for the in vitro investigations.

\section{Preparation}

The cells were centrifuged at $1800 \mathrm{rpm}$ for 2 minutes. Two $\mathrm{mL}$ of cell suspension, with a density of $1 \times 10^{5}$ cells/ $\mathrm{mL}$ DMEM medium, were seeded in the test-tubes and incubated at $37^{\circ} \mathrm{C}$ for 24,48 , and $72 \mathrm{hrs}$. The medium of the 24-hour cell cultures was changed either with a normal one (control cultures) or with one containing the bioactive polyphenolic samples in a dose of $30 \mu \mathrm{g} / \mathrm{mL}$ ).

After another 24 and respectively 48 hours of in vitro development, the growth medium was decanted from the test cultures, the cells were washed with TFS (saline phosphate buffer) and analyzed for total protein content (using the Lowry method modified by Oyama) (Lowry et al., 1951; Oyama et al., 1956)

In order to evaluate cellular proliferation, the cytometric method in a continuous flow system was used (flow-cytometer Beckman Cell Lab Quanta SC) with carboxyfluorescein succinimidyl ester (CFSE). The specific emission of fluorescein (FITC) was registered with the blue laser at
$488 \mathrm{~nm}$. The process of cellular apoptosis was observed by the same method, using fluorochromes 7-AAD (7-Aminoactinomycin D, connecting to the nuclear DNA) and annexine-5 FITC (bound to the phosphatidylserine expressed on the internal surface of the apoptotic cellular membranes (Coder, 2003; Lyons et al., 2003; Macey, 2007).

The significance of the cytostatic effects (inhibition of protein synthesis, mito-inhibitory effects perturbing cellular viability and apoptosis) as well as the cytotoxic action (ratio of live vs. dead cells) were calculated according to a comparative analysis between results obtained from the present study and standard values stipulated in International American and American programs of in vitro prescreening for the selection of new potential anti-neoplasic agents (Leiter et al., 1965; Takimoto, 2003).

All tests were done with 5 replicates. Statistical significances were tested according to the t-test (Cann, 2002).

\section{Results and discussion}

The concentrated vegetal extracts obtained from seeds, skins, grape pomace and lees (yeast deposit after fermentation) were characterized according to their content of total polyphenols, anthocyanins, dry matter, ash and $\mathrm{pH}$ ( Tab. 1). Total polyphenolic extracts from seeds have a concentration of $25.3 \mathrm{~g}$ gallic acid/L, while the anthocyanins in skins reached 2293.7 acid gallic/L.

The dry matter content of seed extracts is $48.8 \mathrm{mg} / \mathrm{L}$, contrary to skin extracts of $138.6 \mathrm{mg} / \mathrm{L}$. The extracts from the fermentation by-products pomace and lees have both low contents of polyphenols and anthocyanins.

In view of the complex nature of polyphenolic and anthocyanic plant extracts and their cytostatic and/or cytotoxic effects, is it necessary to refer the results to a dry matter basis $(\mathrm{mg} / \mathrm{mL})$. Therefore, in the present experi-

Tab. 1. Physico-chemical characteristics of concentrated polyphenolic extracts obtained from the 'Arcaş' grape variety

\begin{tabular}{cccccc}
\hline Parameters & U.M & Seed & Skin & Pomace & Lees \\
\hline Total polyphenols & g galic acid/L & 25.3 & 11.6 & 4.4 & 1.8 \\
Anthocyans & g galic acid/L & - & 2293.7 & 17.5 & 17.5 \\
Dry substance & $\mathrm{mg} / \mathrm{L}$ & 48.8 & 138.6 & 41.6 & 29.0 \\
$\mathrm{pH}$ & & 5.5 & 5.6 & 5.5 & 5.6 \\
\hline
\end{tabular}

Tab. 2. Protein concentration ( $\mu$ g protein/culture) of HeLa tumor culture cells of different ages, and their growing conditions in the presence of tested $30 \mu \mathrm{g} / \mathrm{mL}$ polyphenolic extracts

\begin{tabular}{cccccccc}
\hline \multirow{2}{*}{ Experimental sample } & 24 hours & \multicolumn{2}{c}{48 hours $(24$ hours of treatment) } & \multicolumn{3}{c}{72 hours (48 hours of treatment) } \\
\cline { 2 - 8 } & $\mathrm{X} \pm \mathrm{ES}$ & $\mathrm{X} \pm \mathrm{ES}$ & $\mathrm{t}$ & $\mathrm{p}<$ & $\mathrm{X} \pm \mathrm{ES}$ & $\mathrm{t}$ & $\mathrm{p}<$ \\
\hline Control sample & $148.5 \pm 9.0(5)$ & $212.3 \pm 10.4(5)$ & - & - & $298.5 \pm 16.0(5)$ & - & - \\
Seeds extract & $148.5 \pm 9.0(5)$ & $125.5 \pm 9.0(5)$ & 6.33 & 0.001 & $84.5 \pm 12.1(5)$ & 10.70 & 0,001 \\
Skins extract & $148.5 \pm 9.0(5)$ & $205.8 \pm 9.5(5)$ & 0.46 & N.S. & $314.3 \pm 13.0(5)$ & 0.77 & N.S. \\
Grape pomace extract & $148.5 \pm 9.0(5)$ & $190.5 \pm 11.0(5)$ & 1.44 & N.S. & $263.3 \pm 5.0(5)$ & 2.11 & N.S. \\
Lees extract & $148.5 \pm 9.0(5)$ & $200.6 \pm 12.5(5)$ & 0.72 & N.S. & $284.5 \pm 13.82$ & 0.67 & N.S. \\
\hline
\end{tabular}

Note: Figures in brackets indicate the number of replicates 
218

ment, concentrations were calculated according to this parameter.

The results of the in vitro reactivity of human nature HeLa cancerous cells to concentrated polyphenolic extracts from the 'Arcaş' variety will be presented in what follows. The in vitro research focused on the interference of the bio-active compounds with the protein synthesis, mitosis and cellular apoptosis and on their impact on cellular viability.

In a first trial, the in vitro interaction between polyphenolic and anthocyanic structures of the extracts was analyzed at $30.0 \mathrm{mg} / \mathrm{mL}$ on protein biosynthesis of HeLa malign cells and their impact on total cellular protein concentration. Protein synthesis determined during culture evolution and culture development, as well as HeLa cells reactivity with certain polyphenolic compounds in comparison to the control sample, were also analyzed. The average protein contents observed at different stages, are presented in Tab. 2. The number in brackets indicates the number of replicates.

Total protein concentration increases in the control sample during the time course from 24 to $72 \mathrm{hrs}$. This progressive growth indicates the intensification of cellular protein-synthesis, together with the development of the

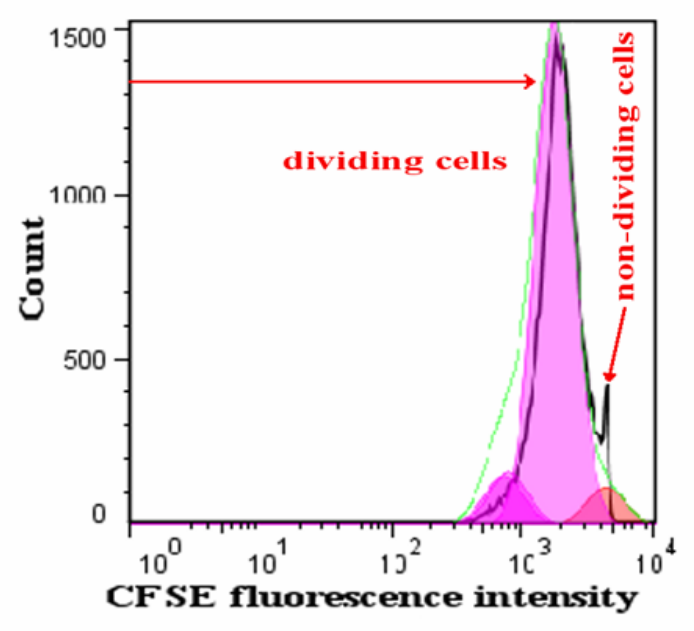

Control sample

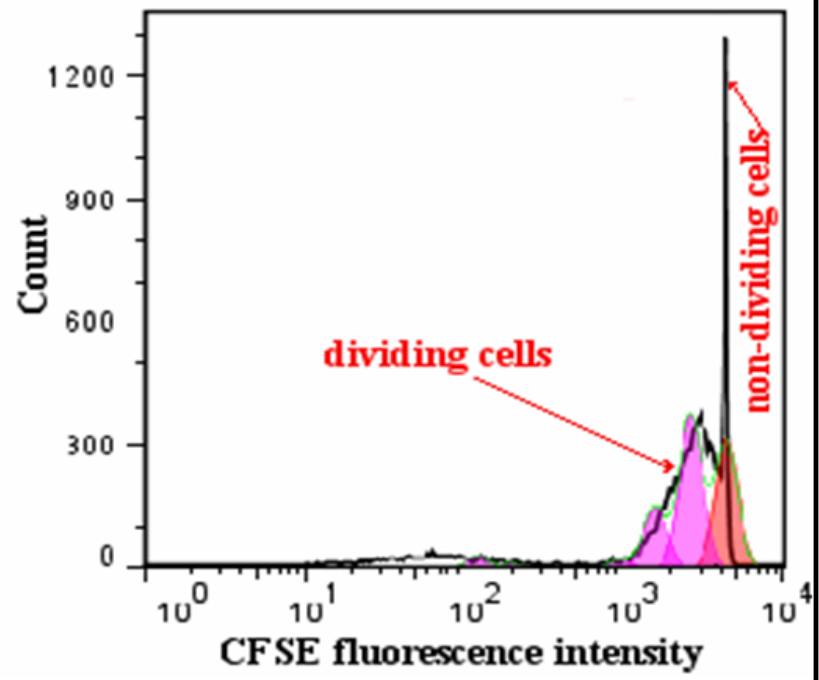

Seed extract

A.

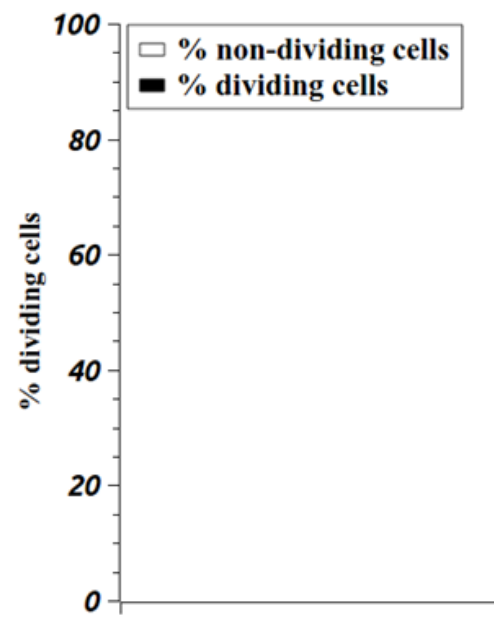

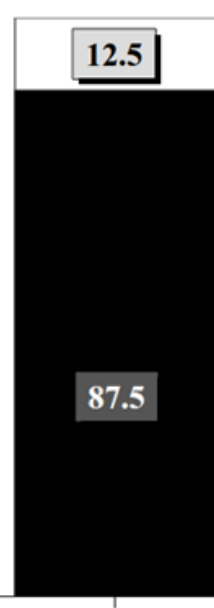

Control

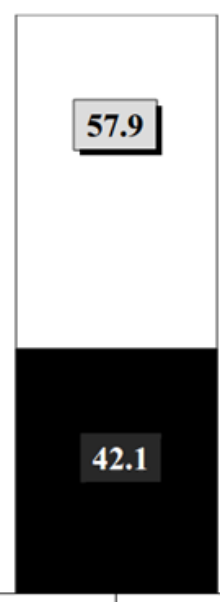

Seeds extract

\section{B.}

Fig. 1. Characteristics of cell proliferation process of HeLa human cancer cells incubated with seeds extract in the active cytostatic dose of $30 \mu \mathrm{g} / \mathrm{mL}$ ( $\mathrm{A}=$ amplitude and fluorescence of the nondividing or dividing cells; $\mathrm{B}=$ percentual quantification of the cell sub-populations) 
Tab. 3. Degree of HeLa cells cultures development in the presence of polyphenolic extracts $(30 \mu \mathrm{g} / \mathrm{mL})$

\begin{tabular}{cccc}
\hline \multirow{2}{*}{$\begin{array}{c}\text { Experimental } \\
\text { variant }\end{array}$} & $\begin{array}{c}24 \text { hours } \\
\text { Development of } \\
\text { cellular cultures } \\
(\%)\end{array}$ & $\begin{array}{c}\text { Development of } \\
\text { cellular cultures } \\
(\%)\end{array}$ & $\begin{array}{c}72 \text { hours } \\
\text { Development of } \\
\text { cellular cultures } \\
(\%)\end{array}$ \\
\hline Control sample & 100 & 100 & 100 \\
\hline Seeds extract & 100 & 59.11 & 28.31 \\
\hline Skins extract & 100 & 96.94 & 105.30 \\
$\begin{array}{c}\text { Grape pomace } \\
\text { extract }\end{array}$ & 100 & 89.73 & 88.21 \\
\hline Lees extract & 100 & 94.49 & 95.31 \\
\hline
\end{tabular}

cellular multiplication rate, showing a normal development of control cultures.

HeLa cultures, treated with seed extract, had lower protein contents after 72 hours, compared to the control sample. This indicates that seed extracts may be a powerful inhibitor of protein synthesis in HeLa cultures in vivo. Grape pomace and wine lees in a similar dose showed nearly no effect in the in vitro test. The reduction in protein content is not significant. Skin extract seems to stimulate protein synthesis, but the effect is not significant.

Another aspect is presented in Tab. 3, illustrating the interaction between polyphenolic extract and the degree of growth inhibition of HeLa cells.

In comparison to the control cultures, seed, skin, pomace and lees extracts reduced more or less the development degree of HeLa cells cultures after 48 and respectively 72 hours treatments. Thus, it can be observed that the seed extract induced a significant regression of cultures during its entire period of evolution, while the other ones had a minimum and insignificant inhibitory impact. The inhibiting potential of the extracts on the development of $\mathrm{HeLa}$ cells cultures is dependent on the origin of the extract. The most active is the seed extract, which reduced the development with $40.89 \%$ (after a treatment of 24 hours, at a 48 hours age) and $71.69 \%$ (after a treatment of 48 hours, at 72 hours age). The skin, pomace and respectively, lees extracts have perturbed the cultures development only by $3.1 \%$ (in the first case), $10.3 \%$ or $11.8 \%$ (in the second case) and respectively, by $5.5 \%$ or $5.0 \%$ (in the third case).

Because of the low reactivity of the HeLa cells protein synthesis process and of cell cultures development to the action of our skin, pomace and lees extracts, it has been considered opportune their exclusion from the ulterior cell oncobiology investigations for evaluation of the cytostatic property of some new Vitis vinifera polyphenolic by-products.

Another action of the cytostatic substances could be exerted upon the cell proliferation process. Thus, it has been followed the interaction of the bioactive seeds polyphenolic biopreparation with the HeLa human neoplastic cells mitosis. The cell division process of the HeLa cell cultures treated with seeds by-product showed remarkable quantitative changes (Fig.1 A and B).

It can be observed from the flowcytometrical highlighting and quantification of the cell proliferation-expressed by inverse proportion relationship between the daughter cells number (increased) and their fluorescence intensity

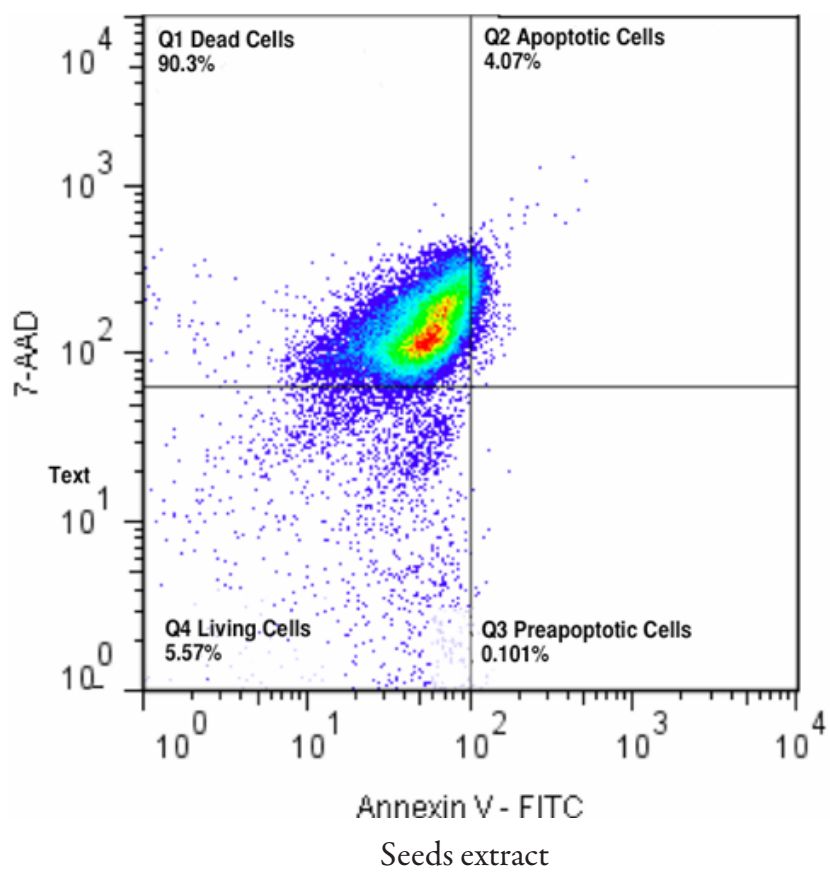

Fig. 2. Bivariate analysis Annexin V/7-AAD of the effect, induced by seed extract $(30 \mu \mathrm{g} / \mathrm{mL})$, on the percentual distribution of preapoptotic, apoptotic, dead and alive cells sub-populations from control and treated HeLa tumor cells cultures 
220

(decreased), which is evaluated by cell proliferation analysis module of the FlowJo software-that:

- a great number of dividing cells and an attenuated fluorescence of the daughter cells have characterized the untreated, control HeLa cells cultures;

- a small number of dividing cells and an intense fluorescence, have characterized the daughter cells of the treated HeLa cells cultures.

These findings argue the inducing of a significant mitoinhibitory effect upon HeLa cells proliferation process by Vitis vinifera seeds polyphenolic extract. The interaction of the bioactive agent, with the cellular structures implied in the cell division, blocks cells in the interphase before entering cell mitosis.

Our results are partially confirmed by in vitro and in vivo recent studies that have shown anti-tumor effects on some human cancers (such as breast cancer, lung cancer and gastric adenocarcinoma, etc.) of the polyphenolic treatments with grape seed extracts (Kaur et al., 2009; Savin et. al., 2009; Singh et al., 2004; Tyagi et al., 2003). However, others researchers have registered an enhancement of the growth and viability of normal human gastric mucosal cells, indicating a lack of toxicity (Ray et al., 2001; Yamakoshi et al., 2002).

Recent studies of Liu et al. (2009), Engelbrecht et al. (2007), Kaur et al. (2006) on cancer cells cultures highlighted the induction of cell apoptosis with proanthocyanidinic extracts from Vitis vinifera seeds.

Consequently, it has been evaluated, by flow cytometry, the effect of the seeds extract upon the apoptosis process and viability of HeLa cancerous cells. The sense and scale of the cell apoptosis and viability reactivity can be observed in Fig. 2.

It can be observed, from the Fig. 2, that in the composition of the control HeLa cells cultures a lot of live cells, very few dead cells, extremely rare apoptotic cells and no pre-apoptotic cells are found, thus untreated cultures are characterized by great cell viability. Contrary, the HeLa cells cultures treated for 48 hours with a dose of $30 \mu \mathrm{g} /$ $\mathrm{mL}$ seeds polyphenolic extract have presented a very great number of dead cells, a very low number of live cells, extremely rare pre-apoptotic cells and very few apoptotic cells.

Generally speaking, the highlighting of a negligible number of apoptosis and pre-apoptosis cells in the composition of the treated HeLa cell cultures or their weak representation in the analyzed cells population suggest the lack of a direct interaction between the seeds polyphenolic byproduct and the molecular structures implied in triggering of the cell apoptosis process. In other words, its cytostatic effect was not induced by an apoptotic mechanism.

The present study has also evidenced a great number of dead cells in the composition of the treated HeLa cell cultures, their existence pointing out that the bioactive agent induced a major decrease of the cells viability. Thus, its cytotoxic potential is proved.
The bulk ofthe present results has demonstrated the in vitro antitumoral property of the seeds polyophenolic by-product-expressed by regression of the HeLa cell cultures-which is conditioned by the complementarity of its cytostatic and cytotoxic actions, they being induced by inhibitory effect upon cell protein synthesis and mitosis, as well as by decrease of cell viability degree.

\section{Conclusions}

The obtained results in the context of the complex evaluation of the in vitro antitumoral property of the extracts, obtained from seeds, skins, grape pomace and wine lees from the 'Arcaş' grape variety, on HeLa cells cultures, have demonstrated the significant cytostatic and cytotoxic potential of the seeds polyphenolic biopreparate.

Its antitumoral action, expressed by regression of the cell cultures, is due to the inhibitory impact upon the cell protein synthesis and mitosis, as well as to the decrease of the cell viability.

\section{Acknowledgments}

This work was co-financed from the European Social Fund through Sectorial Operational Programme Human Resources Development 2007-2013, project number POSDRU/I.89/1.5/S62371 "Postdoctoral School in Agriculture and Veterinary Medicine area.

\section{References}

Baydar NG, Ozkan G, Sagdic O (2004). Total phenolic contents and antibacterial activities of grape (Vitis vinifera $\mathrm{L}$.) extracts. Food Control 15(33):335-339.

Birt DF, Pelling JC, Nair S, Lepley D (1996). Diet intervention for modifying cancer risk. Prog Clin Biol Res 395:223-234.

Cann AJ (2002). Maths from scratch for biologists. John Wiley and Sons Ltd Ed., $240 \mathrm{p}$.

Cheng M, Gao HQ, Xu L, Li BY, Zhang H, Li XH (2007). Cardioprotective effects of grape seed proanthocyanidins extracts in streptozocin induced diabetic rats. J Cardiovasc Pharmacol 50:503-509.

Coder MD (2003). Assessment of cell viability, 1-14 p. In: Robinson P, Darzynkiewicz Z, Hoffman R, Nolan J, Rabinovitch P, Watkins $S$ (Eds.). Current protocols in cytometry. John Wiley and Sons Ltd, West Sussex.

Doyle A, Griffiths JB (1998). Cell and tissue culture, laboratory procedures in biotechnology, John Wiley and Sons Ltd, West Sussex, $332 \mathrm{p}$.

Engelbrecht AM, Mattheyse M, Ellis B, Loos B, Thomas M, Smith R, Peters S, Smith C, Myburgh K (2007). Proanthocyanid in from grape seeds inactivates the PI3-kinase/PKB pathway and induces apoptosis in a colon cancer cell line. Cancer Lett 258(1):144-53.

Hong WK, Sporn MB (1997). Recent advances in chemopre- 
vention of cancer. Science 278:1073-1077.

Hosu AD, Cimpoiu C, Miclaus V, Jantschi L (2011). Antioxidant content of three different varieties of wine grapes. Biotechnol Biotec Eq 25(1):2217-2221.

Hosu AD, Cimpoiu C, Pop N, Miclăus V, Bolboaca S, Jantschi $L$ (2011). The analisys of different factors affecting the red wines antioxidant content. Not Bot Horti Agrobo 39(1): 159-164.

Liu J, Zhuang Q, Zhang W, Wang Y, Chen X, Peng E, Liu F (2009). Role of survivin in apoptosis induced by grape seed procyanidin extract in human bladder cancer BIU87 cells. Chin Ger J Clin Oncol 8(7):429-425.

Joi N, Santosh K (2010). Skin photoprotection by natural polyphenols: anti-inflammatory, antioxidant and DNA repair mechanisms. Arch Dermatol Res 302:71-83.

Katalinic V, Generalic I, Skroza D, Ljubenkov I, Teskera A, Konta I, Boban M (2009). Insight in the phenolic composition and antioxidative properties of Vitis vinifera leaves extracts. Croat J Food Sci Technol 1(2):7-15.

Kaur M, Agarwal C, Agarwal R (2009). Anticancer and cancer chemopreventive potential of grape seed extract and other grape-based products. J Nutr 139:1806S-1812S.

Kaur M, Agarwal R, Agarwal C (2006). Grape seed extract induces anoikis and caspase-mediated apoptosis in human prostate carcinoma LN-CaP cells possible role of ataxia telangiectasia mutated-p53 activation. Mol Cancer Ther 5:1265-1274.

Kaur M, Singh RP, Gu M, Agarwal R, Agarwal C (2006). Grape seed extract inhibits in vitro and in vivo growth of human colo-rectal carcinoma cells. Clin Cancer Res 12:6194-6202.

Leifert W, Abeywardena M (2008). Cardioprotective actions of grape polyphenols. Nutr Res 28(11):729-737.

Leiter J, Abbott DJ, Schepartz SA (1965). Screening data from the cancer chemotherapy national service center screening laboratories. Cancer Res 25: 20-35.

Lowry OH, Rosebrough NJ, Farr AL, Randall RJ (1951). Protein measurement with the folin phenol reagent. J Biol Chem 193:265-275.

Lyons B, Doherty K (2003). Flow Cytometric Analysis of Cell Division by Dye Dilutionin, 1-10 p. In: Robinson P, Darzynkiewicz Z, Hoffman R; Nolan J, Rabinovitch P, Watkins S (Eds.). Current Protocols in Cytometry. John Wiley and Sons Ltd, West Sussex.

Macey MG (2007). Flow cytometry: principles and applications, Humana Press Totowa, New Jersey, 290 p.
Oyama VI, Eagle H (1956). Measurement of cell growth in tissue culture with a phenol reagent (Folin-Ciocalteau). Proc Soc Experiment Biol Med 91(2):305-307.

Park EJ, Pezzuto JM (2002). Botanicals in cancer chemoprevention. Cancer Metastasis Rev 21:231-255.

Paun Roman G, Neagu E, Moroeanu V, Radu GL (2008). Concentration of Symphytum officinale extracts with cytostatic activity by tangential flow ultrafiltration. Rom BiotechnolLett 13(6):4008-4013.

Ray S, Bagchi D, Lim PM, Bagchi M, Gross SM, Kothari SC, Preuss HG, Stohs SJ (2001). Acute and long-term safety evaluation of a novel IH636 grape seed proanthocyanidin extract. Res Commun Mol Pathol Pharmacol 109:165-197.

Ribereau-Gayon P (1965). Le dosage des anthocyanes dans le vin rouge. Bull Soc Chim Paris 9:260-341.

Savin C, Pincu R, Cosmin M, Mantaluta A, Vasile A, Pasa R, Damian D, Cojocaru D (2009). Synthesis of some total polyphenolic extracts from the Vitis vinifera seeds and the study of their cytostatic and cytotoxic activities. Revista de Chimie 60(4):363-367.

Singh RP, Tyagi AK, Dhanalakshmi S, Agarwal R, Agarwal C (2004). Grape seed extract inhibits advanced human prostate tumor growth and angiogenesis and upregulates insulinlike growth factor binding protein-3. Int J Cancer 108:733-740.

Singleton VL, Rossi JA jr (1965). Colorimetry of total phenolics with phosphomolybdic-phosphotungsticacid reagents, Amer J Enol Viticult 16(3):144-158.

Takimoto CH (2003). Anticancer drug development at the US National Cancer Institute. Cancer Chemother Pharmacol 52 (Suppl 1):S29-S33.

Tyagi A, Agarwal R, Agarwal C (2003). Grape seed extract inhibits EGF-induced and constitutively active mitogenic signaling but activates JNK in human prostate carcinoma DU145 cells: possible role in antiproliferation and apoptosis. Oncogene 22:1302-1316.

T,ârdea C, Sârbu G, Țârdea A (2010). Treatise of wine-making, "Ion Ionescu de la Brad” Ed., Iași, 766 p (in Romanian).

Yamakoshi J, Saito M, Kataoka S, Kikuchi M (2002). Safety evaluation of proan- thocyanidin- rich extract from grape seeds. Food Chem Toxicol 40:599-607.

Youdim KA, Mcdonald J, Kalt W, Joseph J (2002). Potential role of dietary flavonoids in reducing microvascular endothelium vulnerability to oxidative and inflammatory insults. J Nutr Biochem 13:282-288. 